GRASAS Y ACEITES $72(2)$

April-June 2021, e403

ISSN-L: 0017-3495

https://doi.org/10.3989/gya.1146192

\title{
Chemical compositon, antibacterial and antioxidant activities of Cnidium silaifolium ssp. orientale (Boiss.) Tutin essential oils
}

\author{
$\oplus$ A.E. Karadağ $\breve{g}^{\mathrm{a}, \mathrm{b}, \bowtie}, \oplus$ B. Demircic ${ }^{\mathrm{c}}, \oplus \mathrm{O}$. Çeçen ${ }^{\mathrm{d}}, \oplus \mathrm{F}$. Tosun ${ }^{\mathrm{a}}$ and $\oplus \mathrm{F}$. Demirci ${ }^{\mathrm{c} e}$ \\ ${ }^{a}$ School of Pharmacy, Department of Pharmacognosy, Istanbul Medipol University, 34810, Istanbul, Turkey \\ ${ }^{\mathrm{b}}$ Graduate School of Health Sciences, Department of Pharmacognosy, Anadolu University, Eskişehir, Turkey \\ 'Faculty of Pharmacy, Department of Pharmacognosy, Anadolu University, 26470, Eskişehir, Turkey \\ dDepartment of Plant and Animal Production, Medical and Aromatic Plants Programme, Ermenek Vocational High School, Karamanoğlu \\ Mehmetbey University, 70400, Ermenek, Karaman, Turkey. \\ ${ }^{\mathrm{e}}$ Faculty of Pharmacy, Eastern Mediterranean University, Famagusta, N. Cyprus, Mersin 10, Turkey \\ ${ }^{\square}$ Corresponding author: ayseesraguler@gmail.com
}

Submitted: 28 November 2019; Accepted: 07 April 2020; Published online: 03 June 2021

SUMMARY: The chemical compositions of the essential oils (EOs) obtained by hydrodistillation from different parts of Cnidium silaifolium ssp. orientale (Boiss.) Tutin were analyzed both by GC-FID and GC/MS, simultaneously. One hundred nine compounds representing $90.1 \%$ of the total volatiles in the EOs were identified with the main characteristic compounds $\alpha$-pinene (50.3\%) in the root, germacrene D (20.3\%) in the fruit, and $\beta$-caryophyllene (18.7\%) in the aerial parts of C. silaifolium ssp. orientale. The antimicrobial activity against human pathogenic Gram-negative and Gram-positive bacteria was evaluated by the in vitro microdilution method. Antibacterial succeptibility was observed from the root and aerial part EOs against Staphylococcus aureus (0.039 and 0.156 mg/mL, respectively); while the fruit EO was most effective against Bacillus cereus at $0.07 \mathrm{mg} / \mathrm{mL}$. The antioxidant capacities of the EOs were also evaluated by in vitro $\mathrm{DPPH} \bullet$ and ABTS $\bullet+$ scavenging assays, where no significant activity was observed compared to ascorbic acid and Trolox.

KEYWORDS: Antimicrobial; Antioxidant; Apiaceae; Cnidium silaifolium ssp. orientale

RESUMEN: Composición química, actividades antibacterianas y antioxidantes de Cnidium silaifolia ssp. orientale (Boiss.) de aceites esenciales de tutin. Se analizó por GC-FID y GC-MS la composición química de los aceites esenciales (AE) obtenidos por hidrodestilación de diferentes partes de Cnidium silaifolium ssp. orientale (Boiss.) tutin. Ciento nueve compuestos, que representan el $90.1 \%$ del total de volátiles de los AE, se identificaron. Los compuestos característicos principales fueron $\alpha$-pineno (50.3\%) en la raíz, germacreno D $(20.3 \%)$ en la fruta y $\beta$-cariofileno $(18.7 \%)$ en las partes aéreas de C. silaifolium s sp. orientale. La actividad antimicrobiana contra bacterias Gram negativas y Gram positivas patógenas humanas se evaluó mediante el método de microdilución in vitro. La susceptibilidad antibacteriana contra Staphylococcus aureusse observó desde la raíz a la parte aérea AEs (0.039 y 0.156 mg/ $\mathrm{mL}$, respectivamente), mientras que la fruta EO fue más efectiva contra Bacillus cereus a $0.07 \mathrm{mg} / \mathrm{mL}$. La capacidad antioxidante de los AE también se evaluó mediante ensayos de eliminación in vitro de DPPH• y ABTS•+, donde no se observó actividad significativa en comparación con el ácido ascórbico y Trolox.

PALABRAS CLAVE: Antimicrobiano; Antioxidante; Apiacea; Cnidium silaifolium ssp. orientale

Citation/Cómo citar este artículo: Karadağ AE, Demirci B, Çeçen Ö, Tosun F, Demirci F. 2021. Chemical compositon, antibacterial and antioxidant activities of Cnidium silaifolium ssp. orientale (Boiss.) Tutin essential oils. Grasas Aceites 72 (2), e403. https://doi. org/10.3989/gya.1146192

Copyright: (C2021 CSIC. This is an open-access article distributed under the terms of the Creative Commons Attribution 4.0 International (CC BY 4.0) License. 


\section{INTRODUCTION}

Cnidium silaifolium ssp. orientale (Boiss.) Tutin of Apiaceae is the only representative of the Cnidium species in Turkey, and is known as "galyabişotu" (Yüzbaşığlu et al., 2018). Previous Cnidium studies reported acaricidal, antioxidant, antipruritic, anticancer, hepatoprotective, and anti-inflammatory activities $(\mathrm{Oh}$ et al., 2002; Jeong et al., 2009; Li et al., 2015; Hong et al., 2017; Lim et al., 2018; Tran et al., 2018; Kim et al., 2018). However, there are only a few previous reports on the essential oil (EO) compositions,where aerial parts were investigated in two different studies (Kapetanos et al., 2008; Polat et al., 2011).

There are very few studies on $C$. silaifolium ssp. orientale and the EO compositions of its aerial parts were investigated previously in two different studies (Kapetanos et al., 2008; Polat et al., 2011). So far, the EO composition of $C$. silaifolium ssp. orientale fruit and root parts have not been characterized. Here, comparative EO compositions of the aerial parts, fruits, and roots of C. silaifolium ssp. orientale were reported using gas chromatography with flame ionization detector (GC-FID) and mass spectrometry (GCMS) systems. Natural products are an important resource for antimicrobial agents, and the essential oils are useful for many applications due to their antimicrobial properties. Antimicrobial essential oils are used as aromas, cosmetics and pharmaceuticals (Arici et al., 2005; Selim, 2011; Başer and Buchbauer 2016). Because of this, the antibacterial and antioxidant activities of the aforementioned EOs were determined by broth microdilution and DPPH - ABTS radical scavenging methods, respectively.

The aim of this present study was to evaluate the in vitro antimicrobial and antioxidant activities of the different parts of $C$. silaifolium ssp. orientale EOs. To the best of our knowledge, this is the first comparative study on the chemistry of the volatiles and biological activities of the EOs from different parts of C. silaifolium ssp. orientale from its natural habitat in Turkey. The EOs were extracted by hydrodistillation followed by chromatographic analyses, and in vitro biological evaluation using selected human pathogenic strains and DPPH and ABTS radicals as scavenger targets.

\section{MATERIALS AND METHODS}

\subsection{Plant material}

The aerial parts, fruits, and roots of $C$. silaifolium ssp. orientale were collected in 16 July 2018 in Ermenek, Balkusan Village. The plant was identified by ÖmerÇeçen and the voucher specimen (Herbarium No: 28000) was deposited at the Herbarium of the Selcuk University (KNYA), Konya, Turkey.

\subsection{Hydrodistillation}

Air-dried aerial parts, fruits, and roots (100 g) were crushed and hydrodistilled by distilled water (200 mL) using a Clevenger apparatus (ILDAM LTD., Ankara, Turkey) for eight hours, individually. The obtained EOs were dried by anhydrous sodium sulfate (Sigma, Germany) and kept in suitable conditions at $4{ }^{\circ} \mathrm{C}$ until $\mathrm{GC}$ and GC/MS analyses as well as biological assays were performed.

\subsection{Chromatographic analyses}

GC/MS analyses of the essential oils were performed using an Agilent 5975 GC-MSD system, (SEM Ltd., Istanbul, Turkey) where an HPInnowax FSC column $(60 \mathrm{~m} \times 0.25 \mathrm{~mm}, 0.25 \mu \mathrm{m}$ film thickness, Agilent, Walt \& Jennings Scientific, Delaware, USA) was used with Helium as carrier gas with a $0.8 \mathrm{~mL} / \mathrm{min}$ flow rate. The $\mathrm{GC}$ oven temperature was maintained at $60^{\circ} \mathrm{C}$ for $10 \mathrm{~min}$. The oven was set to $220^{\circ} \mathrm{C}\left(4^{\circ} \mathrm{C} / \mathrm{min}\right)$, and kept for 10 min. and then heated to $240{ }^{\circ} \mathrm{C}\left(1^{\circ} \mathrm{C} / \mathrm{min}\right)$. The split ratio was set to $40: 1$. The injection temperature was $250{ }^{\circ} \mathrm{C}$. The Mass Spectra (MS) were recorded at 70 $\mathrm{eV}$, and the mass ranges were from $\mathrm{m} / \mathrm{z} 35$ to 450 .

FID temperature was set to $300^{\circ} \mathrm{C}$ for $\mathrm{GC}$ analyses using an Agilent $6890 \mathrm{~N}$ system (SEM Ltd., Istanbul, Turkey). Simultaneous auto-injection was applied using the same conditions as described in the GC/MS part. Relative percentages (\%) of the detected volatile compounds were determined. Identification of these compounds was carried out by comparing their linear retention indexes (LRI) to a series of $\mathrm{C}_{9}-\mathrm{C}_{20} n$-alkane standard solutions (Fluka, Buchs, Switzerland). Computer matching was carried out using commercial (Wiley GC/MS Library, MassFinder Software 4.0), and the in-house 'Başer Library of Essential Oil Constituents' library as well as the literature was performed (Demirci et al., 2018). 
TABLE 1. The Chemical composition of Cnidium silaifolium ssp. orientale essential oils

\begin{tabular}{|c|c|c|c|c|c|}
\hline *RRI & Compounds & $\begin{array}{l}* * \mathrm{CsH} \\
\%\end{array}$ & $\begin{array}{l}* * \mathrm{CsF} \\
\%\end{array}$ & $\begin{array}{l}* * \operatorname{CsR} \\
\%\end{array}$ & $* * * \mathbf{I M}$ \\
\hline 1032 & $\alpha$-Pinene & 0.2 & 0.6 & 50.3 & $t_{\mathrm{R}}, \mathrm{MS}$ \\
\hline 1035 & $\alpha$-Thujene & - & $\operatorname{tr}$ & - & MS \\
\hline 1076 & Camphene & - & - & 0.6 & $t_{\mathrm{R}}, \mathrm{MS}$ \\
\hline 1093 & Hexanal & - & - & 0.2 & $t_{\mathrm{R}}, \mathrm{MS}$ \\
\hline 1118 & $\beta$-Pinene & 0.1 & 0.1 & 1.8 & $t_{\mathrm{R}}, \mathrm{MS}$ \\
\hline 1132 & Sabinene & 0.1 & 0.2 & 1.2 & $t_{\mathrm{R}}, \mathrm{MS}$ \\
\hline 1174 & Myrcene & 0.1 & 0.8 & 4.0 & $t_{\mathrm{R}}, \mathrm{MS}$ \\
\hline 1176 & $\alpha$-Phellandrene & - & - & 0.5 & $t_{\mathrm{R}}, \mathrm{MS}$ \\
\hline 1183 & $p$-Mentha-1,7(8)-diene (=Pseudolimonene) & - & - & 0.1 & MS \\
\hline 1197 & Methyl hexanoate & - & - & 0.1 & $t_{\mathrm{R}}, \mathrm{MS}$ \\
\hline 1203 & Limonene & 0.1 & 0.5 & 5.4 & $t_{\mathrm{R}}, \mathrm{MS}$ \\
\hline 1218 & $\beta$-Phellandrene & - & 0.1 & 3.6 & $t_{\mathrm{R}}, \mathrm{MS}$ \\
\hline 1246 & $(Z)-\beta$-Ocimene & 0.1 & 0.2 & 4.5 & MS \\
\hline 1255 & $\gamma$-Terpinene & - & 0.1 & 1.0 & $t_{\mathrm{R}}, \mathrm{MS}$ \\
\hline 1266 & $(E)$ - $\beta$-Ocimene & 0.1 & 0.2 & 0.8 & MS \\
\hline 1280 & p-Cymene & $\operatorname{tr}$ & 0.1 & - & $t_{\mathrm{R}}, \mathrm{MS}$ \\
\hline 1290 & Terpinolene & - & $\operatorname{tr}$ & - & $t_{\mathrm{R}}, \mathrm{MS}$ \\
\hline 1294 & $1,2,4$-Trimethyl benzene & - & - & 0.2 & MS \\
\hline 1296 & Octanal & - & - & 0.1 & $t_{\mathrm{R}}, \mathrm{MS}$ \\
\hline 1355 & $1,2,3$-Trimethyl benzene & - & - & 0.1 & MS \\
\hline 1400 & Nonanal & - & 0.1 & - & $t_{\mathrm{R}}, \mathrm{MS}$ \\
\hline 1429 & Perillene & - & - & 0.1 & $t_{\mathrm{R}}, \mathrm{MS}$ \\
\hline 1452 & $\alpha, p$-Dimethylstyrene & - & - & 0.2 & MS \\
\hline 1452 & 1-Octen-3-ol & - & - & 0.1 & MS \\
\hline 1466 & $\alpha$-Cubebene & 0.3 & 0.1 & - & MS \\
\hline 1477 & 4,8-Epoxyterpinolene & - & - & 0.4 & MS \\
\hline 1479 & $\delta$-Elemene & - & 0.1 & - & MS \\
\hline 1492 & Cyclosativene & 0.6 & - & - & MS \\
\hline 1497 & $\alpha$-Copaene & 7.5 & 5.3 & 0.3 & MS \\
\hline 1499 & $\alpha$-Campholene aldehyde & - & - & 0.6 & MS \\
\hline 1519 & 1,7-Diepi- $\alpha$-Cedrene ( $=\alpha$-Funebrene) & 0.4 & 0.3 & - & MS \\
\hline 1520 & 3,5-Octadien-2-one & - & - & 0.1 & MS \\
\hline 1535 & $\beta$-Bourbonene & 0.4 & 0.2 & - & MS \\
\hline 1549 & $\beta$-Cubebene & 1.0 & 2.0 & - & MS \\
\hline 1553 & Linalool & $\operatorname{tr}$ & $\operatorname{tr}$ & 0.1 & $t_{\mathrm{R}}, \mathrm{MS}$ \\
\hline 1571 & trans- $p$-Menth-2-en-1-ol & - & - & 0.1 & MS \\
\hline 1577 & $\alpha$-Cedrene & 1.1 & 0.7 & - & $t_{\mathrm{R}}, \mathrm{MS}$ \\
\hline 1586 & Pinocarvone & - & - & 0.2 & $t_{\mathrm{R}}, \mathrm{MS}$ \\
\hline 1597 & $\beta$-Copaene & 0.4 & - & - & MS \\
\hline 1600 & $\beta$-Elemene & 2.1 & 13.7 & - & MS \\
\hline 1604 & Thymol methyl ether (=Methyl thymol) & - & - & 0.4 & $t_{\mathrm{R}}, \mathrm{MS}$ \\
\hline 1611 & Terpinen-4-ol & 2.0 & - & - & $t_{\mathrm{R}}, \mathrm{MS}$ \\
\hline 1612 & $\beta$-Caryophyllene & 18.7 & 11.3 & 0.1 & $t_{\mathrm{R}}, \mathrm{MS}$ \\
\hline
\end{tabular}




\begin{tabular}{|c|c|c|c|c|c|}
\hline *RRI & Compounds & $\begin{array}{l}* * \mathrm{CsH} \\
\%\end{array}$ & $\begin{array}{l}* * \mathrm{CsF} \\
\%\end{array}$ & $\begin{array}{l}* * \operatorname{CsR} \\
\%\end{array}$ & $* * * \mathbf{I M}$ \\
\hline 1614 & Carvacrol methyl ether (=Methyl carvacrol) & - & - & 0.3 & $t_{\mathrm{R}}, \mathrm{MS}$ \\
\hline 1614 & Acora-2,4-diene & - & 0.3 & - & MS \\
\hline 1648 & Myrtenal & & - & 0.2 & MS \\
\hline 1650 & $\gamma$-Elemene & $\operatorname{tr}$ & 0.1 & - & MS \\
\hline 1670 & trans-Pinocarveol & - & - & 0.7 & $t_{\mathrm{R}}, \mathrm{MS}$ \\
\hline 1668 & $(Z)-\beta$-Farnesene & 1.2 & 0.4 & - & MS \\
\hline 1683 & trans-Verbenol & - & - & 1.2 & $t_{\mathrm{R}}, \mathrm{MS}$ \\
\hline 1687 & $\alpha$-Humulene & 2.5 & 6.0 & & $t_{\mathrm{R}}, \mathrm{MS}$ \\
\hline 1690 & Cryptone & - & - & 0.4 & MS \\
\hline 1693 & $\beta$-Acoradiene & 1.0 & 0.6 & - & MS \\
\hline 1700 & $p$-Mentha-1,8-dien-4-ol (=Limonen-4-ol) & - & - & 0.1 & $t_{\mathrm{R}}, \mathrm{MS}$ \\
\hline 1704 & $\gamma$-Muurolene & - & 1.2 & - & MS \\
\hline 1704 & $\gamma$-Curcumene & - & 1.6 & - & MS \\
\hline 1706 & $\alpha$-Terpineol & 2.2 & - & - & $t_{\mathrm{R}}, \mathrm{MS}$ \\
\hline 1725 & Verbenone & - & - & 0.3 & $t_{\mathrm{R}}, \mathrm{MS}$ \\
\hline 1726 & Germacrene D & 9.2 & 20.3 & - & $t_{\mathrm{R}}, \mathrm{MS}$ \\
\hline 1742 & $\beta$-Selinene & 2.2 & 3.4 & - & MS \\
\hline 1744 & $\alpha$-Selinene & 1.3 & 1.3 & - & MS \\
\hline 1751 & Carvone & - & - & 0.1 & $t_{\mathrm{R}}, \mathrm{MS}$ \\
\hline 1755 & Bicyclogermacrene & 1.4 & 0.6 & - & MS \\
\hline 1773 & $\delta$-Cadinene & 5.7 & - & - & MS \\
\hline 1783 & $\beta$-Sesquiphellandrene & - & 4.4 & - & MS \\
\hline 1786 & ar-Curcumene & 2.9 & 5.1 & 0.2 & MS \\
\hline 1796 & Selina-3,7(11)-diene & - & 1.5 & - & MS \\
\hline 1797 & $p$-Methyl acetophenone & - & - & 0.2 & MS \\
\hline 1804 & Myrtenol & - & - & 0.3 & MS \\
\hline 1827 & $(E, E)$-2,4-Decadienal & - & - & 0.1 & MS \\
\hline 1845 & trans-Carveol & 0.3 & - & 0.5 & $t_{\mathrm{R}}, \mathrm{MS}$ \\
\hline 1849 & Cuparene & & 0.2 & - & MS \\
\hline 1854 & Germacrene-B & 0.5 & 2.0 & - & MS \\
\hline 1864 & $p$-Cymen-8-ol & 0.2 & - & 1.4 & MS \\
\hline 1868 & (E)-Geranyl acetone & - & 0.1 & - & MS \\
\hline 1870 & Hexanoic acid & - & - & 0.2 & $t_{\mathrm{R}}, \mathrm{MS}$ \\
\hline 1878 & 2,5-Dimethoxy-p-cymene & - & - & 0.1 & MS \\
\hline 1900 & epi-Cubebol & - & 0.1 & - & MS \\
\hline 1925 & 2,3,4-Trimethyl benzaldehyde & - & - & 0.2 & MS \\
\hline 1941 & $\alpha$-Calacorene & 0.7 & $\operatorname{tr}$ & - & MS \\
\hline 1945 & 1,5-Epoxy-salvial(4)14-ene & 0.2 & 0.1 & - & MS \\
\hline 1957 & Cubebol & - & 0.1 & - & MS \\
\hline 1984 & $\gamma$-Calacorene & - & 0.1 & - & MS \\
\hline 2001 & Isocaryophyllene oxide & - & 0.1 & - & MS \\
\hline 2008 & Caryophyllene oxide & 3.4 & 1.3 & - & $t_{\mathrm{R}}, \mathrm{MS}$ \\
\hline 2019 & 2,3,6-Trimethylbenzaldehyde & 3.9 & - & 1.6 & $t_{\mathrm{R}}, \mathrm{MS}$ \\
\hline 2037 & Salvial-4(14)-en-1-one & 1.3 & 0.1 & - & MS \\
\hline
\end{tabular}




\begin{tabular}{|c|c|c|c|c|c|}
\hline *RRI & Compounds & $\begin{array}{l}* * \mathrm{CsH} \\
\%\end{array}$ & $\begin{array}{l}* * \mathrm{CsF} \\
\%\end{array}$ & $\begin{array}{l}* * \operatorname{CsR} \\
\%\end{array}$ & $* * * \mathbf{I M}$ \\
\hline 2050 & (E)-Nerolidol & 0.4 & - & - & $t_{\mathrm{R}}, \mathrm{MS}$ \\
\hline 2071 & Humulene epoxide-II & 0.6 & 0.1 & - & MS \\
\hline 2084 & Octanoic acid & - & - & $\operatorname{tr}$ & $t_{\mathrm{R}}, \mathrm{MS}$ \\
\hline 2100 & Heneicosane & - & 0.1 & - & $t_{\mathrm{R}}, \mathrm{MS}$ \\
\hline 2109 & cis-Methyl isoeugenol & - & - & 0.2 & MS \\
\hline 2131 & Hexahydrofarnesyl acetone & 0.1 & - & - & MS \\
\hline 2144 & Spathulenol & 5.9 & 0.8 & - & MS \\
\hline 2161 & Muurola-4,10(14)-dien-1-ol & $\operatorname{tr}$ & 0.1 & - & MS \\
\hline 2192 & Nonanoic acid & $\operatorname{tr}$ & 0.1 & - & $t_{\mathrm{R}}, \mathrm{MS}$ \\
\hline 2200 & 3,4-Dimetil-5-pentyl-5H-furan-2-one & $\operatorname{tr}$ & $\operatorname{tr}$ & & MS \\
\hline 2239 & Carvacrol & - & - & 0.1 & $t_{\mathrm{R}}, \mathrm{MS}$ \\
\hline 2242 & Methyl palmitate & - & - & 0.2 & MS \\
\hline 2255 & $\alpha$-Cadinol & - & 0.1 & - & MS \\
\hline 2262 & Ethyl palmitate & - & - & $\operatorname{tr}$ & MS \\
\hline 2273 & Selin-11-en- $4 \alpha$-ol & - & 0.4 & - & MS \\
\hline 2278 & Torilenol & 0.1 & 0.1 & - & MS \\
\hline 2324 & $\begin{array}{l}\text { Caryophylla-2(12),6(13)-dien-5 } \alpha \text {-ol } \\
\text { (=Caryophylladienol II) }\end{array}$ & 0.7 & - & - & MS \\
\hline 2369 & Eudesma-4(15),7-dien-4 $\beta$-ol & - & 0.2 & - & MS \\
\hline 2392 & Caryophylla-2(12),6-dien-5 $\beta$-ol (=Caryophyllenol II) & 1.0 & - & - & MS \\
\hline 2456 & Methyl oleate & - & - & 0.1 & $t_{\mathrm{R}}, \mathrm{MS}$ \\
\hline 2509 & Methyl linoleate & - & - & 0.3 & $t_{\mathrm{R}}, \mathrm{MS}$ \\
\hline \multirow[t]{8}{*}{2655} & Benzyl benzoate & 5.9 & 0.4 & 0.7 & $t_{\mathrm{R}}, \mathrm{MS}$ \\
\hline & Monoterpene Hydrocarbons & 0.8 & 2.9 & 73.7 & \\
\hline & Oxygenated Monoterpenes & 4.7 & $\operatorname{tr}$ & 7.3 & \\
\hline & Sesquiterpene Hydrocarbons & 61.1 & 82.8 & 0.6 & \\
\hline & Oxygenated Sesquiterpenes & 13.6 & 3.6 & & \\
\hline & Fatty acid+esters & $\operatorname{tr}$ & 0.1 & 0.9 & \\
\hline & Others & 9.9 & 0.7 & 4.4 & \\
\hline & Total & 90.1 & 90.1 & 86.9 & \\
\hline
\end{tabular}

*RRI Relative retention indices calculated against $n$-alkanes , \% calculated from FID data; $\operatorname{tr}$ Trace $(<0.1 \%)$

${ }^{* *} \mathrm{CsH}$ : aerial parts, $\mathrm{CsF}$ : fruits. CsR: $C$. roots

***Method of Identification by $t \mathrm{R}$ : retention times of standards on the HP Innowax column ${ }^{\mathrm{a}}$; MS: Mass spectra identified on the basis of computer matching with those of the Wiley and MassFinder libraries and comparison with literature data

\subsection{Antimicrobial activity}

The antimicrobial activity of the Eos was determined using the broth microdilution assay as described before (Karadag et al., 2019). Acinetobacter baumanii ATCC 19606, Salmonella typhi ATCC 6539, Bacillus cereus ATCC 14579, Staphylococcus aureus ATCC 6538, and Listeria monocytogenes ATCC 19115 strains were grown in Mueller Hinton Broth (MHB, Merck, Germany). All microorganisms were standardized to $1 \times 10^{8} \mathrm{CFU} / \mathrm{mL}$ using McFarland No: 0.5 in sterile saline $(0.85 \%)$ using a tubidometer (Biolab, Turkey). Intially, stock solutions of each essential oil and standard antimicrobial agent were prepared in diluted DMSO, serial dilutions were prepared and each strain along with the diluted samples were added to the wells and then allowed to incubate at $37^{\circ} \mathrm{C}$ for 24 hours (Karadağ et al., 2019).

Helicobacter pylori ATCC 43504 was inoculated for 24 hours in Brucella broth containing 5\% (v/v) 
horse blood Colombia agar (Oxoid, Germany) and containing $10 \%(\mathrm{v} / \mathrm{v})$ fetal bovine serum (FBS, Sigma Aldrich, Germany) at $37{ }^{\circ} \mathrm{C}$ in an anaerobic incubation system $\left(5 \% \mathrm{CO}_{2}\right)$. After the incubation, $100 \mu \mathrm{L}$ of $1: 10$ diluted and density adjusted pathogenic strain were put onto each microplate (Karadağ et al., 2019).

Mycobacterium avium was inoculated in Middlebrook 7H11 agar (Sigma Aldrich) and incubated at $37{ }^{\circ} \mathrm{C}$ under aerobic conditions for 4-5 days. Subsequently cultures were vortexed, and after $30 \mathrm{~min}$. diluted bacterial suspensions $\left(10^{6} \mathrm{CFU} / \mathrm{mL}\right)$ were added to each well and then allowed to incubate at $37{ }^{\circ} \mathrm{C}$ for 5 days. The minimum inhibitory concentrations (MIC) were determined by XTT staining and the results were calculated as a mean of three repetitions. The standard antimicrobial compounds were Chloramphenicol, as shown in Table 3. (Chung et al., 1995; Sun et al., 2007).

\subsection{Antioxidant activity}

\subsubsection{DPPH radical scavenging assay}

The antioxidant capacity was determined in terms of hydrogen donating or radical scavenging ability using 2,2-diphenyl-1-picrylhydrazyl $(\mathrm{DPPH} \bullet$ ) (Sigma, Germany) for its capability to bleach the stable radical (Blois 1958). The reaction mix contained $100 \mu \mathrm{M} \mathrm{DPPH} \cdot$ in methanol and EOs at $1 \mathrm{mg} / \mathrm{mL}$ concentration. After $30 \mathrm{~min}$, absorbance was read at $517 \mathrm{~nm}$ by using a UV-Vis spectrophotometer (UV-1800, Shimadzu, Japan) at $25 \pm 2{ }^{\circ} \mathrm{C}$.

Ascorbic acid (Merck, USA) was used as the reference, methanol was used for negative control. $\mathrm{IC}_{50}$ values were determined from a calibration curve, where each experiment was performed in triplicate (Blois 1958; Okur et al., 2018).

\subsubsection{ABTS radical scavenging assay}

The total antioxidant activity of the EOs was measured using the ABTS · assay (Re et al., 1999). ABTS • was produced by reacting ABTS • (Sigma, Germany) with $2.45 \mathrm{mM}$ potassium persulfate. The mixture was left at room temperature overnight. Then, the colored ABTS radical cation was diluted with ethanol. The absorbances were measured at $734 \mathrm{~nm}$ at room temperature. In the assay Trolox (Supelco, Italy) was used as a positive control, as well as the water-soluble $\alpha$-tocopherol (SigmaAldrich, Germany) analogue and blank ethanol was used for negative control. The assays were performed in triplicate.

\section{RESULTS AND DISCUSSION}

Comparative EO compositions of the aerial parts, fruits, and roots of $C$. silaifolium ssp. orientale were were reported using gas chromatography with flame ionization detector (GC-FID) and gas chromatographymass spectrometry (GC-MS) systems. The air-dried root, fruit, and aerial part materials were hydro distilled in a Clevenger-type apparatus for 8 hours to yield a lightyellow oil. The C. silaifolium ssp. orientale aerial part, fruit, and root oil yields were $0.9 \%(\mathrm{v} / \mathrm{w}), 1.2 \%(\mathrm{v} / \mathrm{w})$, $0.7 \%(\mathrm{v} / \mathrm{w})$, respectively which were consequently analyzed both by GC-FID and GC-MS simultaneously. One hundred-nine compound were identified in $C$. silaifolium ssp. orientale EOs obtained from different parts constituting approximately $90 \%$ of the total oil. The aerial part and fruit EOs were dominated by sesquiterpene hydrocarbons. Otherwise, the EO of the root consisted of monoterpene hydrocarbons, mainly. These compounds are listed in Table 1 with their relative percentages. The main components were found to be $\beta$-caryophyllene (18.7\%), germacrene $\mathrm{D}(9.2 \%)$, $\alpha$-copaene (7.5\%), spathulenol (5.9\%), benzyl benzoate $(5.9 \%)$ for aerial part; $\alpha$-pinene $(50 \%)$, limonene (5.4\%), (Z)- $\beta$-ocimene (4.5\%) and myrcene (4\%)

TABLE 2. Antioxidant activity of $C$. silaifolium $\mathrm{ssp}$. orientale essential oils ( $1 \mathrm{mg} / \mathrm{mL}$ concentration)

\begin{tabular}{lllll}
\hline & & \multicolumn{2}{c}{$\mathbf{I C}_{\mathbf{5 0}} \pm$ SD $(\mathbf{m g} / \mathbf{m L})$} \\
& CsH & CsF & CsR & References \\
\hline DPPH· & $1.32 \pm 0.05$ & $1.28 \pm 0.17$ & $1.45 \pm 0.03$ & $0.004 \pm 0.001$ (Ascorbic acid) \\
ABTS & $1.14 \pm 0.06$ & $0.91 \pm 0.07$ & $1.29 \pm 0.07$ & $0.015 \pm 0.008$ (Trolox) \\
\hline
\end{tabular}

**CsH: aerial parts, CsF: fruits. CsR: $C$. roots 
TABle 3. Antimicrobial activity of C. silaifolium ssp. silaifolium essential oils (MICs in $\mathrm{mg} / \mathrm{mL}$ )

\begin{tabular}{llllllll}
\hline $\begin{array}{l}\text { Bacteria } \\
\text { Sample }\end{array}$ & St & Sa & Lm & Ab & Hp & Bc & Ma \\
\hline CsH & $>10$ & $\mathbf{0 . 1 5 6}$ & 0.625 & $>10$ & $>10$ & 0.625 & $>10$ \\
CsF & $>10$ & $>10$ & $>10$ & $>10$ & $>10$ & $\mathbf{0 . 0 7 8}$ & $>10$ \\
CsR & $>10$ & $\mathbf{0 . 0 3 9}$ & 0.625 & $>10$ & $>10$ & 1.25 & $>10$ \\
Chloramphenicol & 0.062 & 0.007 & 0.001 & 0.125 & 0.007 & 0.031 & - \\
\hline
\end{tabular}

(- control) DMSO. **CsH: aerial parts, CsF: fruits. CsR: C. roots St: Salmonella typhii Sa: Staphyllococcus aureus Lm: Listeria monocytogenes Ab: Acinetobacter baumanii Hp: Helicobacter pylori Bc: Bacillus cereus Ma: Mycobacterium avium

$\beta$-phellandrene (3.6\%) for root; germacrene $\mathrm{D}(20.3 \%)$, $\beta$-elemene $(13.7 \%), \quad \beta$-caryophyllene $(11.3 \%)$ and $\alpha$-humulene $(6 \%)$ for fruit EO, respectively. In previous studies, the EOs of the aerial parts of $C$. silaifolium ssp. orientale from two different localities were analyzed (Kapetanos et al.,2008; Polat et al.,2011). One of the studies was $C$. silaifolium ssp. orientale from Central Balcan, which was investigated for its EO composition and $\alpha$-pinene was found to be the main component in this study (Kapetanos et al., 2008). In other respects, the EO composition of $C$. silaifolium ssp. orientale aerial parts from Turkey was analyzed and kessane was found to be the main component of the EO composition (Polat et al., 2011). The first five main components were found to be completely different compared to these two previous studies. Also, in this present study, compared to previous studies, it was seen that the content in EO was investigated more as a percentage and that more compounds were detected than in other studies (Kapetanos et al.,2008; Polat et al., 2011). These differences can be considered to be due to the collection of plant materials from different locations and different seasons. It is possible to see from the results that location differences in plants can change the phytochemistry of plants and hence biological activities.

The results for DPPH and ABTS radical scavenging activities are shown in Table 2. According to the $\mathrm{DPPH} \cdot$ testing system, free radical scavenging activity $\mathrm{IC}_{50}$ value of $C$. silaifolium ssp. orientale aerial part, fruit, and root EOs were determined as $1.32,1.28$, and $1.45 \mathrm{mg} / \mathrm{mL}$, respectively. For the ascorbic acid results $(0.004 \mathrm{mg} / \mathrm{mL})$ the oils were less effective than those of the ascorbic acid standard. In addition, the ABTS radical scavenging activity was also found at moderate levels $(1.14,0.91$, and 1.29 $\mathrm{mg} / \mathrm{mL}$ ) and the results were compared to the Trolox standard $(0.015 \mathrm{mg} / \mathrm{mL})$.

Selected Gram (-) and (+) bacteria are given in Table $\mathrm{S} 3$ and were subjected to $C$. silaifolium ssp. orientale EOs. Among the tested bacteria in this study, $S$. aureus was the most sensitive to the aerial part and root and $B$. cereus was the most sensitive to the fruit EOs. The growth of $S$. aureus was remarkably inhibited by the EO of $C$. silaifolium ssp. orientale aerial and root parts. These results show that aerial and root EOs of $C$. silaifolium ssp. orientale can be used as a natural antibacterial agent for the prevention of $S$. aureus infections. The results indicated that these volatile oils can be natural and potential antimicrobial agents for wound healing and throat infections.

The biological activities of EOs are often explained by synergistic effects caused by combinations of major components. In previous studies, it was found that a Zantoxylum species and Phlomis cretia EOs, the major components of EO similar to the root EO used in this study, had a moderate antimicrobial activity. as in this study (Tatsadjieu et al.,2003; Aligiannis et al., 2004). The essential oils of $C$. officinale leaves and rhizomes, another Cnidium species, were studied against some human pathogens and moderate activity was detected (Sim and Shin 2014). In particular, the high antimicrobial activity of $C$. officinale leaf essential oil against $B$. cereus is similar to the $C$. silaifolium ssp. orientale leaf essential oil used in this study.

In conclusion, the EOs of the different parts of $C$. silaifolium $\mathrm{ssp}$. orientale have moderate antioxidant activity. In addition, aerial part and root EOs showed 
significant inhibition against $S$. aureus, while $B$. cereus was susceptible to fruit EO. To the best of our knowledge, this is the first comparabe report on the volatiles and in vitro biological activities of $C$. silaifolium ssp. orientale aerial part, root, and fruit EOs.

\section{ACKNOWLEDGMENTS}

Part of this work was presented at the International Symposium on Essential Oil Research 2019, in Vienna, Austria.

\section{REFERENCES}

Aligiannis N, Kalpoutzakis E, Kyriakopoulou I, Mitaku S, Chinou IB. 2004. Essential oils of Phlomis species growing in Greece: Chemical composition and antimicrobial activity. Flavour Fragr. J. 19, 320-324. https://doi.org/10.1002/ ffj. 1305

Arici M, Sagdic O, Gecgel U. 2005. Antibacterial effect of Turkish black cumin (Nigella sativa L.) oils. Grasas Aceites 56, 259-262.

Başer KHC, Buchbauer G. 2016. Handbook of Essential Oils Science, Technology and Applications. 2nd edition. London, CRC Press, 121-130.

Demirci F, Karaca N, Tekin M, Demirci B. 2018. Anti-inflammatory and antibacterial evaluation of Thymus sipyleus Boiss. subsp. sipyleus var. sipyleus essential oil against rhinosinusitis pathogens. Microb. Pathog. 122, 117-121. https://doi.org/10.1016/j.micpath.2018.06.025

Hong H, An JC, De La Cruz JF, Hwang SG. 2017. Cnidium officinale makino extract induces apoptosis through activation of caspase- 3 and p53 in human liver cancer HepG2 cells. Exp. Ther. Med. 14, 3191-3197. https://doi.org/10.3892/ etm.2017.4916

Jeong JB, Ju SY, Park JH, Lee JR, Yun KW, Kwon ST, Lim JH, Chung GY, Jeong HJ. 2009. Antioxidant activity in essential oils of Cnidium officinale makino and Ligusticum chuanxiong hort and their inhibitory effects on DNA damage and apoptosis induced by ultraviolet B in mammalian cell. Cancer Epidemiol. 33, 41-46. https://doi. org/10.1016/j.canep.2009.04.010

Kapetanos C, Karioti A, Bojović S, Marin P, Veljić M, Skaltsa H. 2008. Chemical and principal- component analyses of the essential oils of Apioideae taxa (Apiaceae) from Central Balkan. Chem Biodivers. 5, 101-119. https://doi. org/10.1002/cbdv.200890000

Karadağ AE, Demirci B, Çaşkurlu A, Demirci F, Okur ME, Orak D, Sipahi H, Başer KHC. 2019. In vitro antibacterial, antioxidant, anti-inflammatory and analgesic evaluation of Rosmarinus officinalis L. flower extract fractions. South African J. Bot. 125, 214-220. https://doi.org/10.1016/j. sajb.2019.07.039

Karadag AE, Demirci B, Cecen O, Tosun F. 2019. Chemical characterization of Glaucosciadium cordifolium (Boiss.) B.L. Burtt and P.H. Davis essentialoilsand theirantimicrobial, andantioxidant activities. Istanbul J. Pharm. 49, 77-80. https:// doi.org/10.26650/IstanbulJPharm.2019.19013

Kim K-T, Kim M-H, Park J-H, Lee J-Y, Cho H-J, Yoon I-S, Kim D-D. 2018. Microemulsionbased hydrogels for enhancing epidermal/dermal deposition of topically administered 20(S)protopanaxadiol: in vitro and in vivo evaluation studies. J. Ginseng Res. 42, 512-523. https://doi. org/10.1016/j.jgr.2017.07.005

Li YM, Jia M, Li HQ, Zhang ND, Wen X, Rahman K, Zhang QY, Qin LP. 2015. Cnidium monnieri: A review of traditional uses, phytochemical and ethnopharmacological properties. Am. J. Chin. Med. 43, 835-877. https://doi.org/10.1142/ S0192415X15500500

Lim EG, Kim GT, Kim BM, Kim EJ, Kim SY, Kim YM. 2018. Ethanol extract from Cnidium monnieri (L.) Cusson induces cell cycle arrest and apoptosis via regulation of the p53-independent pathway in HepG2 and Hep3B hepatocellular carcinoma cells. Mol. Med. Rep. 17, 2572-2580. https://doi.org/10.3892/mmr.2017.8183

Oh H, Kim JS, Song EK, Cho H, Kim DH, Park SE, Lee HS, Kim YC. 2002. Sesquiterpenes with hepatoprotective activity from Cnidium monnieri on tacrine-induced cytotoxicity in Hep G2 cells. Planta Med. 68, 748-749. https://doi. org/10.1055/s-2002-33796

Polat T, Özer H, Cakir A, Kandemir A, Mete E, Özturk E, Yildiz G. 2011. Volatile Constituents of Cnidium silaifolium (Jacq.) Simonkai subsp. orientale (Boiss.) Tutin from Turkey. J. Essent. Oil-Bearing Plants 14, 453-457. https://doi.org/ 10.1080/0972060X.2011.10643600 
Selim SA. 2011. Chemical composition, antioxidant and antimicrobial activity of the essential oil and methanol extract of the egyptian lemongrass cymbopogon proximus stapf. Grasas Aceites 62, 55-61.

Sim Y, Shin S. 2014. Antibacterial activities of the essential oil from the leaves and rhizomes of Cnidium officinale Makino. J. Essent. Oil Res. 26, 452-457. https://doi.org/10.1080/10412905. 2014.951456

Tatsadjieu LN, Essia Ngang JJ, Ngassoum MB, Etoa FX. 2003. Antibacterial and antifungal activity of Xylopia aethiopica, Monodora myristica, Zanthoxylum xanthoxyloïdes and Zanthoxylum leprieurii from Cameroon. Fitoterapia 74, 469-472. https://doi.org/10.1016/S0367-326X(03)00067-4

Tran HNK, Cao TQ, Kim JA, Youn UJ, Kim S, Woo MH, Min BS. 2018. Anti-inflammatory activity of compounds from the rhizome of Cnidium officinale. Arch. Pharm. Res. 41, 977-985. https://doi.org/10.1007/s12272-018-1048-9

Yüzbaşığlu S, Altıözlü H, Kandemir A, Özbek MU. 2018. Flora of Kemaliye (Erzincan) District. Hacettepe J. Biol. Chem. 4, 533-557. 